\title{
A Critique of Emergency Rule as a Security Strategy for Conflict Management and Resolution in Nigeria
}

\author{
Dr. Onwe, Sunday O., Nwogbaga, David M. E. \\ Department of Public Administration Ebonyi State University Abakaliki \\ Department of Political Science Ebonyi State University Abakaliki
}

\begin{abstract}
The enforcement of emergency rule as an alternative conflict resolution and management strategy in Nigeria has attracted controversies and criticisms over its relevance, interpretation, and application. Despite the observed defects and failures associated with previous enforcement in the Western region in 1962, Plateau State in 2004, and Ekiti State in 2006, President Goodluck Jonathan after initial refusal to heed various agitations, later declared state of emergency in Borno, Adamawa, and Yobe states largely enveloped by the "Boko Haram" insurgence. While the communitarians who advance emergency rule as an option for peace argued that the welfare of the collective or community must be valued over any individual rights or liberties; the libertarians criticised emergency rule because it deprives certain people of their civil rights. Without prejudice to the arguments of the communitarians and the libertarians, but in the light of the organic theory, it is argued that emergency rule can scarcely resolve crisis permanently especially the ones that are organic and historical in nature because they deal with core issues and interests that are hardly separable and negotiable. Hence, though the emergency rules declared in Borno, Yobe, and Adamawa states may force momentary stoppage of the crisis in the affected areas as in past cases, it may not bring a permanent solution especially if the causes are not adequately addressed.
\end{abstract}

\section{Introduction}

A state of emergency otherwise called Justitium in Roman law is a governmental declaration that may suspend some normal functions of the executive, legislative and judicial powers; alert the citizens to change their normal behaviour or order government agencies to implement emergency preparedness plans (Wikipedia, 2011). It can also be used as a rationale for suspending rights and freedoms even if guaranteed under the constitution (Wikipedia, 2011). Such declarations usually come during time of natural or man-made disaster, periods of civil unrests or following a declaration of war or situations of international or internal armed conflict. Under emergency rule, police powers are extended, constitutional rights suspended and censorship legalised (Shetaha, 2004). The emergency law sharply circumscribes any non-governmental political activity, street demonstrations; and unapproved political organisation, and unregistered financial donations are formally banned (Al-Ahram Weekly, 2011). Three main dispositions concern kinds of emergency rule in time of crisis (Wikipedia, 2011): extra-ordinary powers to the president, regulation of the state of siege, and the suspension of regular procedures. Thus, state of emergency empowers authorities to (a) regulate or forbid circulation and gathering in some areas (including use of curfews); (b) close places of gathering; (c) conduct house to house searches at any time without judicial oversight; (d) censorship; (e) replace civilian authorities with military authorities or name coordinating powers; and (f) override normal administrative processes regarding the passage of powers. In some countries, the state of emergency and its effects on human rights and freedoms, and governmental procedures are regulated by the constitution and/or law that limits the powers that may be invoked. Rights and freedoms may be suspended during an emergency such as the freedom of movement, but not non-derogable rights (Premont et al, 1996). In many countries, it is illegal to modify the emergency law or the constitution within the period of the rule (Wikipedia, 2011).

\section{Review of Related Literatures}

In the review of related literatures, we looked at the perspectives on the use of emergency rule as a conflict resolution strategy, conditions for declaring state of emergency, the principles that guide the declaration/enforcement of emergency rule, and the applicability of the organic theory of state in explaining emergency rule.

\section{Perspectives on Emergency Rule as a Conflict Resolution Strategy}

Arguments in favour and against state of emergency as strategy for conflict resolution culminated in two schools of thought: the communitarians and the libertarians. The communitarians contend that the welfare of the collective or community must be valued over any individual rights or liberties (Rourke and Boyer, 2002). The 
communitarians like Carl Schmitt are pro-emergency rule because it guarantees collective security of an endangered community. This is done by limiting some derogable rights of the individuals. On the other hand, the libertarians represented by Agamben (2005) criticised emergency rule because it deprives certain people of their civil rights. In other words, state of emergency can be abused by invoking it to allow a state suppress internal opposition without having to respect human rights. This was the prime criticism levelled against the declaration of emergency in Nigeria's Western Region in 1962 over crisis in the House of Assembly by Awolowo who noted that there had been more serious crisis in Tiv (Northern Region) and Okrika (Eastern Region), which the Prime Minister, Tafawa Balewa did not invoke the emergency powers (The Guardian, May 19, 2004). Also citing the case of India under the then Prime Minister, Indira Gahndi, amidst allegations of rigged elections, the emergency rule saw prominent opposition leaders being dumped into jails (Wikipedia, 2011).

\section{Conditions for Emergency Rule}

Without prejudice to the contending perspectives, state of emergency can be declared under the following conditions: (a) if the constitution or the authorities it creates are endangered or interrupted by internal unrest or foreign attack; (b) if there is a threat to employment, safety or public order; (c) when institutions of governance, the independence of the nation, the integrity of its territory or the fulfilment of its international commitment are under great and immediate threat (Wikipedia, 2011; Premont et al, 1996; Awolowo, 1962). The identified conditions for declaring state of emergency implies that it can take the forms of public welfare emergency, public order emergency, international emergency, and war emergency. While public welfare emergency relates to the needs, wants and living conditions of the people; public order emergency arises from situations of internal unrests like the Jos crisis. In international emergency, there can be freezing of assets, limiting of trade and confiscation of property of other countries. Moreso, war emergency may be declared in circumstances of invasion and external aggression.

\section{Principles of Emergency Rule}

Essentially, the declaration of state of emergency is guided by some principles which need to be observed. These principles include: legality, notification, proclamation, duration, and proportionality. The principle of legality suggests that the declaration of emergency rule and its execution should be carried out in accordance with the provisions of the constitution; neither the constitution nor the emergency rule, or any part thereof should be amended within the period of emergency to avoid abuse. The notification principle implies that any authority declaring state of emergency is required to inform the concerned subjects of its circumstances, time limitation, and the rights affected; more so, it should be issued in writing and published. In terms of proclamation, the state of emergency should be declared by the appropriate authority and must be publicly done. Furthermore, the duration of the emergency rule should be clearly specified ab initio as well as on extension as the case might be. Importantly, the principle of proportionality holds that the actions taken in respect of the emergency rule must only be to the extent required by the exigencies of the situation; else, it can contribute to escalating the crisis. Observably, the writings of scholars have not explained the extent to which public order emergency rule can address ethno-religious crisis.

\section{The Organic Theory of State and Emergency Rule Application}

The central idea of the organic theory is that like natural organism, the society is a united whole of different parts that must function collectively to realise its common goals. Hence, the society is more than an aggregate of individuals loosely thrown together without any unifying bond and seeks more or less liberty in the limits of state and individual activities to enhance socio-political stability in the process of governance (Appadorai, 1968). It compares the State to an organism, a living structure with different parts in kind; these parts are complementary to one another, and the health of the organism depends on the healthy discharge by each part of its function (Appadorai, 1968). A detailed analogy of the organic theory explained that a society has three systems corresponding to the systems of living organisms: the sustaining system (alimentary canal/manufacturing districts and agricultural areas); the distributive system (Blood vessels/Roads, canals, railways etc); and the regulating system (nerve-motor mechanism/government) respectively. Essentially, the state is seen as a Person: thus, the whole purpose of the constitution is to enable the person of the state to express and realise its will (Bluntschli, 1921). Also, the state has a masculine character in contrast with the feminine character of religion.

Two main theoretical strands are drawn from the organic theory: the communitarians and the libertarians. The communitarians postulated that as nothing that affects the parts can be different to the whole, the state is bound by its laws and government to aim jointly with the citizens at the perfect development of every individual in the community. Hence, a state should have an all-embracing sphere with and for the citizens. It may refrain from unwise interference in special cases, but it has the right to interfere in all; the part must 
therefore be subordinate to, and may be sacrificed for, the welfare of the whole (Leacock, 1921). In contrast to the communitarian postulation, the libertarians aver that State's functions should be limited to the prevention of violence and fraud; while the individual should otherwise be left alone (Barker, 1947). This is because the natural organism is different from the social organism and cannot absolutely have the same behaviour pattern (Appadorai, 1968). The social organism is discrete (physically separate but interdependent) and its purpose is the happiness of the individual to be realised through guaranteeing internal and external security.

Notably, the organic theory has been criticised for: first, the extreme comparison between natural organism and social organism which Barker (1947) and Spencer later distinguished as concrete (physically contiguous and inseparably attached) and discrete respectively without having absolutely the same behaviour pattern; second, the contradictory postulation of the proponents (the communitarians and the libertarians) did not give clear guidance over the limits of state and individual activities to ensure stability in governance (Appadorai, 1968). In other words, accepting the view of the communitarians implies sacrificing the individual for the state; while accepting the libertarian view suggests subjecting the survival of the state to the mercy of individual whims and caprices.

Without prejudice to the observed theoretical defects and differences, the organic theory has some value as it stresses that society is more than an aggregate of individuals loosely thrown together without any unifying bond. Its members are dependent on one another; hence, the welfare of each is involved in the welfare of all. Consequently, the attainment of the common purpose therefore depends on the proper performance by the state and the citizens of their mutual duties and obligations (Appadorai, 1968). The organic theory is therefore useful in reminding the citizens of their obligations to the state, and reminding the state of its duty to guarantee the security of the citizens. Thus, the organic theory is applicable in explaining the relevance of emergency rule in conflict resolution given that state of emergency is concerned with regulating state and individual activities to ensure law and order in the process of governance. Meanwhile, the organic theory explains that it is the collective responsibility of both the state and the individual citizens to attain the common purpose of governance which is to ensure welfare and security in the society. Any attempt to disjoint this organic relationship either between the state and the citizens or among the citizens of common origin, is likely to destabilise the polity; and when the polity is already destabilised, the associated crisis may only be resolved after addressing issues related to the disjointed values; else, emergency rule may not be effective.

\section{The Enforcement of Emergency Rules in Nigeria}

The enforcement of emergency rule in Nigeria is provided in Sections 65 and 305 of the 1960 and 1999 Constitutions respectively. To all intents and purposes, the provisions of these sections are similar. The only difference lies in the fact that under the 1999 Constitution, the concurrence of both the executive and the legislature is needed before an emergency rule can take effect whereas under the 1960 Constitution, it is only a resolution of the Federal Parliament is needed because it prescribed Parliamentary System of Government (Lanlehin, 2004). Subject to the provisions of section 305 of the 1999 Constitution (1) The President may by instrument published in the Official Gazzette of the Government of the Federation issue proclamation of a state of emergency in the Federation or any part thereof; (2) The president shall immediately after the publication, transmit copies of the Official Gazzette of the Government containing the proclamation including the details of the emergency to the President of the Senate and the Speaker of the House of Representative, each of whom shall forthwith convene or arrange for a meeting of the House of which the President or the Speaker, as the case may be, to consider the situation and decide whether or not to pass a resolution approving the proclamation; (3) The President shall have power to issue a proclamation of a state of emergency only when: (a) the Federation is at war (b) the federation is in imminent danger of invasion or involvement in a state of war (c) there is actual breakdown of public order and public safety in the federation or any part thereof to such extent as to require extraordinary measures to restore peace and security (d) there is a clear and present danger of an actual breakdown of public order and public safety in the federation or any part of the Federation thereof requiring extra-ordinary measures to avert such danger (e) there is an occurrence or imminent danger, or the occurrence of any disaster or natural calamity, affecting community or a section of the community in the Federation (f) there is any other public danger which clearly constitutes a threat to the existence of of the Federation ; or ( $g$ ) the President receives a request to do so in accordance with the provisions of subsection 4 of this section. (4) the Governor of a state may with the sanction of a resolution supported by two-thirds majority of the House of Assembly, request the President to issue a Proclamation of a state of emergency in the state when there is in existence within the state any of the situations specified in subsection (3) (c), (d) and (e) of this section and such situation does not extend beyond the boundaries of the state. (5) The President shall not issue a proclamation of a state of emergency in any case to which the provisions of subsection (4) of this section apply unless the governor of the state fails within a reasonable time to make a request to the President to issue such Proclamation. (6) A Proclamation issued by the President under this section shall cease to have effect: (a) if it is revoked by the President by instrument published in the Official Gazette of the government of the Federation; 
(b) if it affects the Federation or any part thereof and within two days when the National Assembly is in session, or within ten days when the National Assembly is not in session, after its publication, there is no resolution supported by two-thirds majority of all the members of each House of the National Assembly approving the proclamation; (c) after a period of six months has elapsed since it has been in force: provided that the National Assembly may, before the expiration of the period of six months aforesaid, extend the period for the Proclamation of the state of emergency to remain in force from time to time for a further period of six months by resolution passed in like manner; or (d) at any time after the approval referred to in paragraph (b) or the extension referred to in paragraph (c) of this subsection, when each House of the National Assembly revokes the proclamation by a simple majority of all the members of each House. It is based on these provisions (also provided in the 1960 Constitution) that we will examine the imposition of emergency rules in the Western Region (1962), Plateau State (2004), and Ekiti State (2006) as to ascertain the trend.

\section{The 1962 Emergency Rule in the Western Region}

Political crisis crept into the Action Group (AG), which was the party in control of the Western government of Nigeria, and it broke into two factions. Consequently, the National Executive of the Party deposed Chief Akintola as Deputy Leader and asked him to resign appointment as premier of Western Nigeria. The Premier, Akintola, on his part advised the Governor of Western Nigeria that in view of the political crisis and the rival claims of the two factions to a majority support of the electorate in the region, he should dissolve the legislative House of the region based on Section 31 of Part III of the 1960 Constitution; but the Governor refused. Akintola also tried to prevail on the Speaker of the House for the same reasons to convene sitting, to consider and pass a motion for a vote of no confidence in the government of Western Nigeria; but the Speaker also refused. On $24^{\text {th }}$ May, 1962, the Governor purported to exercise the powers vested in him by Section 33(10) of the Constitution of Western Nigeria set out in the Fourth Schedule to the Nigerian Constitution Order-inCouncil 1960 and purported to remove Chief Akintola from his office as premier of Western Nigeria with effect from the May 21. Chief Akintola thereupon filed a motion in the high court challenging the power of the governor to remove him from office in the manner he did. Nevertheless, the Governor proceeded to exercise the powers in normal circumstances vested in him by Section 33(1) of the Constitution of Western Nigeria and appointed Chief D.S. Adegbenro to be Premier of Western Nigeria with effect from May 21. Eventually, a meeting for the Western House of Assembly was summoned for May 25 which could not hold as a result of the fight that broke out and the police locked up the Assembly Chamber. In view of this threat to public peace, order, and good governance, the council of ministers met and discussed the situation; which later culminated in the declaration of state of emergency on May 29. As a result:

1. The Regional Governor, and the Premier, were suspended;

2. The Regional House of Assembly, was suspended;

3. An Administrator, Dr. M.A. Majekodunmi, was appointed to run the affairs of the Western Region;

4. Emergency Regulations were signed by Dr. Nnamdi Azikiwe to run the affairs of the region.

5. Restriction Order was signed to limit the movement of some politicians like Obafemi Awolowo, S.L. Akintola, Fani-Kayode, and Biodun Akelere etc.

But all efforts towards reconciling the opposing factions failed even during the period of the emergency rule (Majekodunmi, 1962).

\section{The 2004 Emergency Rule in Plateau State}

The Jos crisis erupted in 2004 between muslim cattle herders and christian farmers over land and cattle; it lasted for four month (February-may). The crisis left in its wake more than 1000 people dead, about 258,000 persons internally displaced and property worth billions of naira destroyed (Global IDP Project, 2005; Osaghae and Suberu, 2005; Ostien, 2009; Nkanga, 2011). This led to the Plateau Peace Conference of 2004 organised within the period of the emergency rule to proffer solution to the Jos crisis. The Plateau Peace Conference met in Jos from 18 August to 21 September, 2004. All indigenous "ethnic nationalities in the state", "pegged at 54", were invited to send two representatives each; 48 indigenous groups responded (Nkanga, 2011). Other major Nigerian ethnic nationalities resident in the state, namely, the Fulani, Hausa, Igbo, people from the south-south (Urhobos, Ijaws and Yorubas) were allowed one representative each, although in the end, the Fulani and Hausa each had two. Some interest groups were also represented: women (one from each local government), various civil society groups and the Christian Association of Nigeria (CAN) and Jama'atu Nasril Islam (JNI), representing christian and muslim interests.

Notably, while the Plateau Peace Conference was still in progress, state of emergency was declared on Tuesday, May 18, 2004 on the ground that the Jos crisis constitute threats to law and order, the security of Plateau State and the neighbouring states, and the unity of Nigeria in general (FRN, 2004). Having exhausted all possible avenues to help the state government ensure security of lives and property, and cognisant of the inability and incompetence of the Governor to maintain security of lives and property in the state and 
particularly in Jos, there was no alternative than to resort to the last constitutional option to ensure peace and security in Plateau State (Obasanjo, 2004; Agba and Abimaje, 2011). Consequently, by the virtue of section 305 of the Constitution of the Federal Republic of Nigeria (1999), a state of emergency was declared in Plateau State. By the declaration:

1. The Governor and his Deputy were suspended and relieved of their executive duties in Plateau State.

2. A retired General, Chris Ali was appointed as an administrator to manage the affairs of Plateau State.

3. The Plateau State House of Assembly was also suspended as the formal legislative body of the state on the contention that having a State Assembly under emergency rule was considered incongruous and would not allow for the expeditious actions that the administrator needed to put the state back into a situation of peace, harmony, security for all, and maintenance of law and order throughout the state.

4. Elected officials below the state level were not suspended.

5. The Federal Gazette containing the Declaration was forwarded to the National Assembly in accordance with the Constitution.

6. It was hoped that the administrator would not need new laws for the administration of the state. But if he does, it would be in the form of regulations, which he would submit to the President for consideration by the Federal Executive Council and promulgated by the president for the state.

But even within the period of, and after, the emergency rule, the Jos crisis still continued (Ostien, 2009; Osaghae and Suberu, 2005; Nkanga, 2011)

\section{The 2006 Emergency Rule in Ekiti State}

The state of emergency declared in Ekiti State on October 27, 2006, resulted from crisis over the governorship position. The House of Assembly had purportedly impeached the Governor, Ayo Fayose, and his Deputy, Biodun Olujimi, in a manner considered unconstitutional by the federal government over allegations of misconducts. Consequently, the State House of Assembly served the notice of impeachment and the Chief Judge of the State empanelled a team to investigate and report to the House of Assembly. However, the State House of Assembly was dissatisfied with the type of people put on the Panel. They were seen as friends of Governor Ayo Fayose and those who would not be objective. But rather than let the legal representative of the House of Assembly object to those considered not likely to be objective or to all of them one by one if need be and which would have compelled the Chief Judge to replace them, the State House of Assembly suspended or rather removed the Chief Judge who refused to reconstitute the membership of the Panel, and replaced him with an Acting Chief Judge. The Speaker of Ekiti State House of Assembly was sworn in as Acting Governor. But Mrs. Olujinmi claimed to remain the constitutional Deputy Governor and the Acting Governor in the absence of Governor Ayo Fayose who was at the same time in hiding, claimed to remain the Governor. We had a sad and ridiculous but unacceptable situation where there were three purported governors in the State.

In addition to the impeachment processes against the Governor, the entire situation was clearly considered pathetic and unconstitutional on three basis: the removal of the Chief Judge, the appointment of a new Chief Judge, and the swearing-in of the Speaker as the Acting Governor. The whole process was considered a clear case of usurpation of power based on the provisions of the constitution. In relation to the removal of a Chief Judge, Section 292 of the Constitution reads: Sub-Section (1) - A judicial officer shall not be removed from his office or appointment before his age of retirement except in the following circumstances: sub-subSection a(ii) - In the case of Chief Judge of a State, Grand Kadi of a Sharia Court of Appeal or President of a Customary Court of Appeal of a State, by the Governor acting on an address supported by two-thirds majority of the House of Assembly of the State, praying that he be removed for his inability to discharge the functions of his office or appointment (whether arising from infirmity of mind or of body) for misconduct or contravention of the code of conduct; (b) in any case, other than those to which paragraph (a) of this sub-Section applies, by the President or, as the case may be, the Governor acting on the recommendation of the National Judicial Council that the judicial officer be so removed for his inability to discharge the functions of his office or appointment (whether arising from infirmity of mind or of body) or for misconduct or contravention of the code of Conduct. Simply put, only an address from the Governor can lead to the removal of a Chief Judge by the State House of Assembly and a recommendation by the National Judicial Council can lead to the removal of an ordinary judicial officer. Neither of these conditions was present in the case of Ekiti State. This makes the act of the State House of Assembly of Ekiti in removing the Chief Judge unconstitutional. Concerning the appointment of a Chief Judge, Section 271(1) of the constitution provides: "The appointment of a person to the office of Chief Judge of a State shall be made by the Governor of the State on the recommendation of the National Judicial Council subject to confirmation of the appointment by the House of Assembly of the State". This suggests that in the process of appointing a Chief Judge of a State, the onus rests with the National Judicial Council, which recommends to the Governor who makes the appointment after confirmation by the State House of Assembly. Here, the job of the House is confirmation and not recommendation nor appointment. Hence, by the act of Ekiti State House of Assembly, they took upon themselves the duty of the Judiciary, (i.e., the National Judicial 
Council) and the duty of the Chief Executive, (i.e., the Governor). On the swearing-in of the Speaker, Friday Aderemi, as the Acting Governor, it was considered that he deliberately manoeuvred and manipulated the entire process for his selfish interests and personal aggrandisement.

Consequent upon the foregoing violations of the constitutional provisions, the then President, Olusegun Obasanjo on October 27, 2006, declared a state of emergency on Ekiti State:

1. The Governor, his Deputy and those who purported to be Acting Governors or Deputy, by the declaration ceased to be in charge of the affairs of Ekiti State.

2. An Administrator, in the person of Brigadier- General Tunji Olurin (rtd.), was appointed to manage the affairs of Ekiti State for six months in the first instance.

3. The Ekiti State House of Assembly was suspended as the formal legislative body of the State with immediate effect for six months. Having a State Assembly in position under a State of Emergency was considered incongruous and could not have allowed for the expeditious actions that the Administrator would need, to put the State back into a situation of peace, harmony, security for all, and maintenance of law and order throughout the State.

4. Elected officials below the State level were not suspended.

5. The Federal Gazette containing the Declaration was forwarded to the National Assembly in accordance with the Constitution.

6. It was hoped that the Administrator would not need new laws for the administration of the State. But if he did, it would be in the form of Regulations which he would submit to the President for consideration by the Federal Executive Council and promulgated by the president for the state.

\section{The 2013 Emergency Rules in Borno, Yobe, and Adamawa States}

The Boko Haram insurgence in Northern Nigeria was responsible for the declaration of emergency rules in Borno, Yobe, and Adamawa States. Given the state of lawlessness which had begun to emerge in those states, spurred by elements using terrorist tactics, with the ultimate objective of destabilizing the Nigerian state, emergency rule was perceived as the last option and focused measure to ensure the rule of law, public order, respect for human rights and dignity, protection of life and property and the maintenance of the sovereignty, popular as well as territorial integrity, of the country. It was believed that the State of Emergency would serve to curtail the criminality and brigandage which had characterised the affected areas. According the President, Goodluck Jonathan, the state of emergency was a necessary step to halt the insurgency of the dreaded Boko Haram members who turned down the offer of dialogue and amnesty extended to them by the Federal Government. The activities of the terrorists have so far "prevented the government from performing its constitutional responsibilities" and caused fear among Nigerians. Hence, in application of its statutory obligation to protect lives and property of all Nigerians and foreign nationals resident in Nigeria; and in response to the escalating security tension and terrorist threats in the North-Eastern Nigerian States of Borno, Yobe and

Adamawa, the Federal Government of Nigeria, on $14^{\text {th }}$ May, 2013, declared a State of Emergency in those States. However, it was appreciable that the usual suspension of democratically elected public office holders was not carried. Hence, in the period of the emergency rule:

1. the governors and other elected officers of the three affected states were not suspended but remained in office during the emergency rule despite the fact that the Governors of Borno and Yobe came from the opposition ANPP while Adamawa's governor came from the President Jonathan's PDP. ; in other words, Political institutions and structures of elected Governments were allowed to operate unhindered.

2. The State of Emergency, was approved by the Nigerian Senate and House of Representatives, and was billed to be lifted as soon as normalcy returns to those States.

3. Presidential Committee on Dialogue and Peaceful Resolution of the Security Challenges in the North, chaired by the Hon. Minister for Special Duties, Mr. Kabiru Turaki, was established to serve as Field oversight of security operatives to complement other civil efforts of the Government towards easing the tension in the States.

\section{Effects of Emergency Rules in Nigeria}

1. The military is overstretched to points of needing international supports as evident in the Baga (Borno State) Massacre that involved the Chadian forces;

2. Greater percentage of the nation's budget is allocated to national security at the expense of the other sectors;

3. It divided the opinions of Nigerians along sectional, religious and in some cases political lines which portends grave danger for Nigeria's unity and democracy;

4. It tends to sustain the military mentality siege in which the crude use of force to maintain law and order is still predominant; 
5. flagrant violations of human rights by security agents; etc

\section{A Critical Analysis of the Emergency Rules}

The state of emergency declarations in Nigeria's western region (1962); Plateau State (2004); Ekiti State (2006); in some local governments spread across four states of Plateau, Yobe, Niger and Borno in December 2011; Borno, Yobe, and Adamawa States (2013) which were more or less Public Order Emergency rules, faced criticisms especially over their constitutionality in three strands: justification, interpretation, and application.

The justification of the emergency rules in addressing the circumstances or problems upon which they were declared was highly contested. It is argued that in the Western Region and Ekiti State, there were no sufficient and actual breakdown of law and order that could justify the imposition of the emergency rules on the grounds that the crisis were neither deep nor prolonged. It was alleged that the imposition of emergency rules was a conspiracy by the Federal Government to take over the Western Nigeria and the Ekiti State Governments because the violent crisis was not extended or prolonged; hence, the crisis situation was considered more or less an opportunity long desired by the federal government (Awolowo, 1962; Elendu, 2006; Aturu, 2006). Thus, there was allegedly no sufficient breakdown of law and order in the Western Region and Ekiti States as to demand the invocation of emergency rule, compared to other cases of crisis with greater intensity (which emergency rules were not invoked) like Tiv Division of Northern Nigeria, and Okrika in the Eastern Region; as well as Kano, and Kaduna States respectively. However, the magnitude of the crisis situation in Jos constituted sufficient threats to public law and order for emergency rule to be declared, but it was considered not worthwhile for two main reasons: first, other crisis resolution strategies had not been exhausted as to resort to the last option. This is because mediation processes (the Plateau State Peace Conference and dialogue by government officials/politicians, as well as Christian-Muslim Dialogue for Peace in Plateau) were still in progress when the emergency rule was declared thereby truncating the efforts (Kukah, 2004). Second, the crisis is organic and historical, and as such, it may not be resolved through repressive means like the emergency rule strategy (Otsanjugu, 2011; Dokun, 2005; Kukah, 2004).

In relation to interpretation, it was contended that the provisions of the constitution were deliberately misinterpreted to serve the interest the beneficiaries. Meanwhile the emergency rules declared on the Western Region, Plateau State, and Ekiti State were criticised for not meeting the demands of the principle of legal interpretations. It was argued that the constitution does not empower the president to suspend the constitutional organs of the government (of Plateau State) by mere executive instrument as that constitutes a subversion of the federal system (Nwabueze, 2004; Adudu, 2004). Importantly, the clause "extra ordinary measures" was ambiguously misinterpreted to back up the former president's arbitrary actions(Nwabueze, 2004). Whereas the phrase "extra-ordinary measures" suggests the deprivation of non-derogable rights of the individuals such as curtailing of movements, extension of police powers, checking and searching without judicial oversights, taking over the security of the state or areas affected, it was misinterpreted to imply the dismantling of constitutionally established democratic structures (the organs of government) through the suspension of executives, legislators, and judges as the cases were (Nwabueze, 2004; Kukah, 2004). Nevertheless, this misinterpretation was partly corrected in the enforcement of the emergency rules under president Jonathan in Yobe, Borno and Adamawa where elected political office holders were not suspended.

The Application of the emergency rules relates to the principle of proportionality. The principle of proportionality did not apply in state of emergency declared because they covered the entire region and states whereas the crisis only affected some areas. In 1962, it was only an intra-party crisis that led to the invocation of the emergency rule on the entire Western Region; in 2004, only Yelwa, Langtang and Wase local government areas of Plateau State were affected in the 2004 crisis, whereas a blanket invocation of the rule was made to cover the whole of the State (Odiaka et al, 2004); in 2006, the crisis was still within the State Capital when the state of emergency was declared on the whole state (Aturu, 2006). But in 2011, the principle of proportionality was applied when state of emergency was declared in some selected council areas of Plateau, Yobe, Niger and Borno states.

\section{Findings}

1. It appears that so far, the public order emergency rules invoked in Nigeria served more or less as an instrument for the extension and advancement of political interests rather than resolving crisis situations. This submission is hinged on the fact that the declarations have been selective and discriminatory.

2. The emergency rules were not able to resolve any of the crisis situation for which they were invoked due to its abuse and politicisation by the declaring authorities. 
3. Except the Jos crisis, the Boko Haram insurgence in Yobe, Borno, and Adamawa; the conflict situations in the Western Region (1962) and Ekiti State (2006) seemed insufficient in both intensity, areas affected, and the duration, as to demand for the invocation of emergency rules.

4. Although the crisis situation in Jos, and Boko Haram insurgence in Yobe, Borno and Adamawa seemed sufficient for the invocation of emergency rule, it was not the appropriate strategy to apply given the organic and historical nature of the crisis which the causes had not been addressed.

5. The ambiguities in the provision of the constitution especially in the clause "Extra-Ordinary Measures", gave room for the misinterpretation and misapplication of emergency rules.

\section{Conclusion and Recommendations}

The emergency rule may force momentary stoppage of crisis in the affected areas, but it may not bring a permanent solution if the causes of the crisis are not properly addressed especially when the conflict issues are organic and historical. The power to proclaim a state of emergency is an extraordinary one that must be used sparingly and only after consultation and dispassionate assessment of the conditions present in the country or any part of it. It is therefore recommended that the President should not proclaim a state of emergency without consulting the Council of State. This would ensure that the President regards the instrument of proclaiming a state of emergency as one of last resort and not to serve the whims and caprices of some politicians or office holders. The membership of the Council of State is fairly representative of the interests of other states of the Federation and should be able to offer calm advice to the Chief Executive of the Federation. If eventually the advice of the Council is disregarded, there is the likelihood that the approval of the Legislature may not be secured since the Senate President, the Speaker of the House, and the 36 State Governors are members of the Council. Alternatively, it may be inserted as a subsection of section 305, that the President must seek a prior approval of the National Assembly in a joint sitting before proclaiming a state of emergency over internal civil unrest. Either of these two proposals may significantly assist in preventing possible abuse of the extraordinary powers and measures to declare a state of emergency and enforce the rules.

\section{References}

[1]. Adudu, cited in Aziken, E. (2004): "Dariye should be removed, but not by Obasanjo", in Vanguard, May 28.

[2]. Agamben, G. (2005): "State of Exception". Chicago: University of ChicagoPress.

[3]. Agba, G. and Abimaje, A. (2011): "State of Emergency not Solution to JosCrisis-Jonathan"; online:allafrica.com/accessed09/02/2011.

[4]. Al-Ahram Weekly (2011): "Emergency Rule in Egypt", online:http://www.allafrica.com/accessed-09/02/2011

[5]. Appadorai, A. (1968): The Substance of Politics. India: Oxford UniversityPress.

[6]. Aturu, B. (2006): "Emergency Rule in Ekiti as the 1999 Constitution Holds", in, The Guardian, October 26.

[7]. Awolowo, O. (1962), in The Guardian (2004): “The 1962 State of Emergency in the Western Region", May 19; p.8

[8]. Barker, E. (1947): Political Thought in England from Spencer to the Present Day. Oxford: Home University Library.

[9]. Bluntschli, J.K. (1921): The Theory of the State. Oxford: Oxford UniversityPress.

[10]. Dokun, O. O. (2005): Conflict and Context of Conflict Resolution. Ile Ife: Obafemi Awolowo University Press Ltd.

[11]. Elendu, J. (2006): "The Imposition of State of Emergency in Ekiti State",online: http://elendureports.com

[12]. Global IDP (2005): "Internal Displacement in Nigeria: A Hidden Crisis"; online: http://www.idpproject.org/accessed-09/02/2011

[13]. Kukah, M. H. (2004): "Plateau: State of Plateau as a Metaphor", in TheGuardian, May 30; p.10

[14]. Lanlehin, F. (2004): “The Reality and Constitutionality of the Plateau Proclamation", in, Vanguard, May 28; p.15

[15]. Leacock, S. (1933): Elements of Political Science. Constable.

[16]. Majekodunmi, M. (1962): "I was not there to fight the Action Group", in, The Guardian, May $19,2004$.

[17]. Nkanga, P. (2011): "Fighting for Identity in the Home of Peace and Tourism", online: http://234next.com/accessed-09/02/2011

[18]. Nwabueze, B. (2004): “The Rape of Constitutionality in Plateau State", inVanguard, June 16.

[19]. Obasanjo, O. (2004): "Emergency Rule Declaration", online:http://www.nigeriangov.org

[20]. Odiaka, P. et al (2004): "The Plateau Conundrum and Strong Measures", in The Guardian, May 20.

[21]. Osaghae, E.E. and Suberu, R.T. (2005): History of Identities, Violence and Stability in Nigeria. CRISE Working paper No. 6; online: http://www.crise.ox.ac.uk

[22]. Ostien, P. (2009): Jonah Jang and the Jasawa: Ethno-Religious Conflict in Jos, Nigeria, online: http://www.sharia-in-

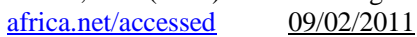

[23]. Otsanjugu, A.T. and Larab, A.T. (2011), in Ahmed, G. (2011): "Jos Crisis: ASUU laments over Government Inability to Safeguard lives, Property”; online: http://www.worldstagegroup.com/accessed 09/02/2011

[24]. Plateau Peace Conference (2004): "Plateau Resolves: Report of the Plateau Peace Conference, 2004" (Jos: Plateau State of Nigeria Gazette, vol.9, No.2; November 11, 2004

[25]. Premont, D. et al (1996): "Non-Derogable Rights and States of Emergency", online:http:www.bruylant.be

[26]. Rourke, J. T. and Boyer, M. A (2002): World Politics: International Politics on the World Stage.

USA:McGraw-Hill BookCompany.

[27]. Shehata, S. (2004): "Egypt after 9/11: Perceptions of the United State",Contemporary Conflicts", in, Social Science Research Council; online:http://conflicts.ssrc.org

[28]. The Guardian (May 19, 2004): "The 1962 State of Emergency in the Western Region", p.8

[29]. The Constitution of the Federal Republic of Nigeria, 1960

[30]. The Constitution of the Federal Republic of Nigeria, 1999

[31]. Wikipedia(2011): "State of Emergency", online:http://en.wikipedia.org/accessed 09/02/11 